\title{
Issues on the Impact of Migration on the Labour Market and the Role of National Employment Agency in the Integration of Returned Migrants in the Republic of Moldova
}

\author{
Raisa DOGARU
}

\begin{abstract}
For the Republic of Moldova, international labour migration is an important factor in overcoming imbalances both in the labour market and in the national economy. International labour migration, through its transfers, contributes to economic growth and the combating poverty. At the same time, labour migration generates certain economic and social risks related, first of all, to the aging population and the increase of the labour force deficit on the labour market. One solution to overcoming these risks would be to stimulate return migration and the integration of returned migrants into employment, an activity that is the responsibility of the National Employment Agency. The analysis of the impact of labour migration on the national economy and the labour market, as well as the role of the Employment Agency in the process of integration of returned migrants is the object of study of this article.
\end{abstract}

Keywords: labour migration, return migration, integration of returned migrants

JEL code: J6

\section{Introduction}

International labour migration can be seen as an important factor in overcoming labour market imbalances for the countries of origin and destination. From the perspective of the destination countries / the latter, the effects of the phenomenon of international migration on the labour market consist in reducing the labour market imbalances, by covering the need for

\footnotetext{
${ }^{1}$ Raisa Dogaru este doctorandă ASEM, Chișinău, Republica Moldova. E-mail: raisa.dogaru@anofm.md.https://orcid.org/0000-0001-9299-4257
} 
labour in areas that are not of interest to the domestic workers, even in the conditions of a high level of unemployment, or due to the lack of qualified personnel. Within the countries of origin, the effects of international labour migration on the labour market are both positive and negative. On the one hand, it can help to eliminate the imbalances between the labour demand and supply, reducing the unemployment and bringing new work experiences, new technological ideas specific to advanced countries. On the other hand, the phenomenon of international labour migration / mobility can also lead to a deficit in the labour market if the working conditions offered are unattractive and there are wage differences compared to those in the destination countries, which discourages the participation in the domestic labour market and promotes the formation of migratory behaviour and culture.

In this context, in order to anticipate unpleasant situations related to the labor shortage in certain segments of the labor market in the Republic of Moldova, the public authorities draw special attention to the expansion of return migration. Thus, the Employment Strategy of the Republic of Moldova for 20172021 directly indicates the creation of effective levers to attract migrants to work at home, and the creation of all favorable conditions for their integration into employment in the Republic of Moldova. The National Employment Agency of the Republic of Moldova has a special role in this process.

The analysis with consideration of these aspects is extremely important when looking for solutions meant to change the existing situation on the labour market in a positive direction oriented towards capitalization and development.

Namely, the analysis of the return migration from the Republic of Moldova and the role of National Employment Agency (NEA) in the integration of labour migrants returned to the labour market from the Republic of Moldova is the object of study of this article.

In order to research the return migration from the Republic of Moldova, the economic effects and the social challenges, several qualitative and quantitative research methods were used, such as: the method of sociological observation, the method of document analysis, the method of statistical analysis. An extensive specialized bibliography was used in the elaboration of the article. The article concludes with relevant conclusions. 


\section{Literature review and data methodology}

In order to successfully carry out this study, a vast literature dedicated to the integration of returned migrants on the labour market was used. Aspects such as labour migration and its impact on development the role of labour migration in expanding the dual labour market (Piore, 2014), and global trends in migration (International Labor Organization) were analyzed. Also, the normative acts and the strategic documents that are currently in force in the Republic of Moldova were analyzed. The analyzes performed in the article were mainly based on the methods of descriptive statistics and document analysis. Statistical data from the National Bureau of Statistics, the National Employment Agency, as well as some data taken from various studies conducted in recent years were used.

\section{Labour migration, contemporary issues}

Migration has become a defining feature of the modern global economy, and the main factors underlying its expansion are the processes of globalization, technical progress, the new economic order, etc. The importance of contemporary migration is linked not only to the number of migrants, but also to the fact that the migratory phenomenon has become global and takes on more and more diverse forms. People travel for various periods of time, but shorter (Сталкер, 2015). They adopt a pattern of circulatory migration, continue to maintain strong connections with where they left off or practice unregulated migration. But with their return home, migrants bring not only money, but also new development ideas, knowledge and new entrepreneurial skills acquired as a result of migration. In this way, migrants obviously contribute to the modernization of the country and play an extremely important role in its intellectual and economic development.

Migration is no longer a phenomenon that affects only those who leave, but also those who remain in the destination country. Thus, contemporary migration has become one of the fundamental elements of social and economic transformation in the contemporary world. In other words, as a multifunctional phenomenon, migration can really be considered a development factor (De Haas Hein, 2007). The migratory factor can have a significant impact on economic development in both countries of origin and destination. 
For the countries of origin, international migration is a sure way to reduce the unemployment, given that the countries face a huge surplus of labour force and do not have the economic capacity to absorb this surplus. The unemployment, as an indicator of macroeconomic instability, is usually determined by the imperfect functionality of the economy, the insufficient volume of investment needed to create new jobs, the unfavorable business environment, the purchasing power of the population, which is weakly, compromises the increase in consumption and, respectively, the economic growth. For destination countries, which are characterized by an aging population, the high pace of economic development, respectively, the accelerated job creation that cannot be covered by the available human potential leads to a labour force shortage. In this situation, the international migration is the way to solve this economic imbalance (labour shortage). It should be noted that the majority of migrant workers are employed in unskilled jobs, for which, in fact, there is the largest shortage of the labour force (Vaculovschi \&Vaculovschi, 2016; Vaculovschi, 2017).

The transfer of knowledge and know-how also comes with a significant contribution to the economic development of the countries of origin and destination. For the countries of origin, the transfer of knowledge is manifested through new experiences and professional skills, through the new business and work culture that returned migrant workers have accumulated in economically developed countries and intend to use them in economic units in developing countries, thus contributing to increased productivity and economic competitiveness. For the destination countries, this type of transfer is manifested by attracting highly qualified migrant workers, so-called specialists who cannot be found in their country of origin.

Technical progress, accompanied by the globalization processes, have led to the emergence of new types of migration such as: intellectual migration, it is determined by the growing demand for a skilled workforce in the destination countries. In this context, an optimal solution to reduce the deficit in this segment of the labour market would be to attract highly qualified staff from abroad, especially since the attraction of foreign professionals also involves the introduction of world experience and new knowledge in the country. The phenomenon related to the departure of qualified specialists from less developed to more developed countries is 
called "brain drain" (Mahroum, 2012). The term "brain drain" has been launched to describe the emigration of engineers and scientists from Europe to the United States, which continues to be the main destination for highly skilled migrants even today. The category of "specialist" (professional worker) has become so important in the research of international migration, that it has become necessary to divide it into subcategories: top managers; engineers; professionals; researchers; entrepreneurs; students. It is considered that the "brain drain" reduces the economic growth, as the countries of origin lose significant human capital as well as investment in education. On the other hand, the phenomenon of 'brain drain' is accompanied by another phenomenon, namely the process of 'brain waste', which takes place when the qualified specialists migrate to the destination countries to provide employment services of inferior qualification, which can lead in the long run to the degradation of human capital. In fact, a waste of human capital can also take place in the situation when the skilled labour force, remaining at home, cannot be fully realized. If the workforce is not used, it loses its qualification anyway.

The transfer of remittances (or financial assets) which is that part of the income of migrant workers that they send home for the support of their families or for some long-term investment plans (purchasing a home or a durable good, starting a business, etc.) can also have a key impact on economic growth (OIM/UNDP/UNWomen/GMG/SDC/GoRM, 2010). The volume of foreign exchange resources coming to the country as remittances is a rather important source for ensuring a decent living for the families whose one or more members are working abroad. In addition to the fact that these resources contribute to increasing the well-being of families whose members are migrant workers, at the macroeconomic level they also contribute to increasing domestic consumption, which in turn stimulates the economic growth. Remittances, turning either into final consumption or into savings that can later be transformed into investment resources, stimulate the growth of aggregate demand (Levitt, 1998).

At present, the international practice offers the following tools for transforming remittances into investments that have been successfully established in certain countries: stimulating collective investment through the collective programs; Mi Comunidad, Native associations; strengthening the 
external diaspora; implementation of specialized international financial products; providing a wide range of services by financial institutions to migrants and their families, debit cards; remittance guidance projects in the development of small and medium-sized enterprises; national projects related to the knowledge and satisfaction of the basic needs of migrants (Orozco \& Welle, 2004).

In recent years, the concept of circular migration has been launched in order to overcome threats related to labour migration, especially of highly qualified specialists, accompanied by a series of immigration policy measures for the countries of origin and destination. Circular migration is an old phenomenon, registered in the context of internal or rural-urban migration. In simple terms, this phenomenon means repeated migratory experiences, more than a departure and a return. Circular and temporary migration reflects the globalization, demographic change, new models of mobility and the growing demand for flexible labour markets. Circular migration is an intensely discussed phenomenon in the world in terms of efficient management as a development potential. The contemporary option for circular migration starts from the fact that it brings more benefits and can be a useful tool for low- and middle-income countries of origin, through investment-generating remittances and trade and business networks, but also by improving the human capital base. It can also contribute to the achievement of the Sustainable Development Goals, although it should not be seen as a panacea for development or a major means of solving more general problems (Burdelnii \& Terzi-Barbăroșie, 2013).

The main benefits of circular migration for migrant workers can be obtained from higher earnings abroad, from remittances transferred, from acquiring or improving skills required in the labour market, as well as from the possibility of good sources of money that can be recovered from investments in developing enterprises. Macroeconomists often describe migrant workers as the flexible "valve" of the European labour market. Among the positive effects of circular migration for countries of origin may be: privileged access to employment and labour markets in destination countries, constant flow of remittances, following repeated waves of migrants, reduced brain drain and return of those competitive, business and enterprise creation by circular migrants, good cooperation with destination countries to strengthen the link between the migration and development. It can be concluded that circular 
migration through its forms of manifestation in various destination countries is becoming more widespread, being development-oriented.

In addition to the economic and social benefits, migration also generates certain social risks, primarily the loss of human capital, demographic imbalances, caused by an aging population, and increasing pressure on the health system, etc. According to classifications made by Francesco Cerase there are four reasons which determines the return of migrants, namely: the return for retirement, the return for innovation, the return from conservatism, the return from failure. Return, especially individual planning, requires information and concrete actions that can be provided by public authorities and non-governmental organizations. (Cassarino, 2004)

\section{Policies of the Republic of Moldova in the field of migration}

Raising awareness of migration as a phenomenon that can produce not only negative social costs but also positive development results for the country and the commitment to manage the challenges and opportunities of migration, has led to various legislative and political activities of the Government of the Republic of Moldova, that recognized the need for a coordinated and integrated approach to migration management (Postolachi et al, 2007). However, the prevalence of emigration and its strong impact on the Republic Moldova indicate the need to assess the reciprocal links between migration and each development sector, and further suggest the need to take this phenomenon into account in public policy-making. In order to promote legal (circular) migration, the Moldovan authorities have continued to expand the legal employment opportunities of Moldovan citizens abroad by concluding / implementing bilateral agreements in the field of labour migration with destination countries, an example being the implementation by the National Employment Agency from 2012 of the Bilateral Agreement between the Government of the Republic of Moldova and the Government of the State of Israel on the temporary employment of citizens of the Republic of Moldova in certain sectors of the State of Israel which is valid today. During the years 2013-2020, several stages of implementation of the Agreement were carried out, and 10179 people were employed with individual employment contracts at over 25 employers in different cities of 
the state of Israel: Tel Aviv, Ashdod, Rishon Le Zion, Jerusalem, Haifa, the persons returned from Israel, on 15.02.2018 - 1681 returned to Moldova. Moldovan workers employed under this Agreement enjoy the same labour rights and obligations as domestic workers. The Republic of Moldova is also actively involved in promoting various circular migration programs. By National Employment Agency in 2020, 5768 individual employment contracts were registered through the private agencies, 37 in number. The countries predominate: Poland with 3903, Germany with 733, the Netherlands with 573, the USA with 253 and Israel with 219 registered contracts (ANOFM Raport, 2020).

The extension of the legal employment opportunities of the citizens of the Republic of Moldova abroad is also one of the key measures stipulated in the National Employment Strategy for the years 2017-2021, approved by GD No. 1473 of 30.12.2016. Thus, the action direction "Strengthening the institutional and legislative framework necessary to manage the labour migration process" under Priority 4. "Unlocking the potential of migration for sustainable development" provides the following: adjusting legislation in the field of labour migration to change from international labour markets (circular migration, respect for the rights of labour migrants, flexicurity, female migration); further development of bilateral and multilateral cooperation with destination countries; improving regulations on the work of private employment agencies in order to increase the legal employment of migrant workers abroad; strengthening the collaboration relations between the private employment agencies and the National Employment Agency (Strategia Națională „Diaspora-2025”, 2017).

A very important instrument for the protection of migrants are the social security and migration agreements with other states, the legal framework being: the revised European Social Charter (art. 12 para. 4), partially ratified by the Republic of Moldova / Law no. 484 of 28.09, Moldova-EU / PNAAA Association Agreement, Moldova 2020 National Development Strategy, Government Activity Program, Cooperation Platforms: Eastern Partnership, Moldova-EU Mobility Partnership, social security agreements, labour migration agreements.

The agreements in the field of social security are very important, the purpose of which is to provide the citizens of the Republic of Moldova with 
pension rights or other social insurance benefits in the states where they work; not to admit the loss of social insurance rights acquired on the territory of the Republic of Moldova, in case of relocation on the territory of another state; thus, ensuring the right of citizens to free movement. To date, the Republic of Moldova has concluded agreements in the field of social security with $18 \mathrm{EU}$ member states: Bulgaria, Portugal, Romania, Luxembourg, Austria, Estonia, Czech Republic, Poland, Hungary, Lithuania, Belgium, Germany etc.

The national strategic documents in the field of migration are: National Program for the implementation of the Action Plan Republic of Moldova European Union in the field of visa liberalization, National Strategy in the field of migration and asylum (2011-2020); National strategy on employment policies for 2017-2021, regulatory framework: Law on employment promotion and unemployment insurance no. 105 of 14.06.2018; Action Plan for the implementation of the National Strategy in the field of migration and asylum; Annual national action plans on employment; The action plan for the implementation of the National Strategic Program in the field of demographic security, etc.

The international instruments include the following: 43 conventions of the International Labour Organization (ILO) ratified by the R. of Moldova, which regulate the labour market and 3 basic conventions in the field of labour migration: European Convention on the Legal Status of Migrant Workers (ratified in 2006); Convention n. 97 of the International Labour Organization on migration for employment (ratified in 2005); Convention n.181 of the ILO on Private Employment Agencies (ratified 2001).

The agreements signed in the field of labour migration with the following states: Russian Federation, Ukraine, Belarus, Azerbaijan, Italy, State of Israel. The draft of a new Agreement between the Government of the Republic of Moldova and the Government of the Russian Federation on cooperation in the field of labour migration and temporary work activity of migrant workers on the territory of the Republic of Moldova and the Russian Federation was finalized for signing. Beneficiaries of Labour Migration Agreements: migrant workers employed in an organized or independent manner, posted workers who are or have been insured in accordance with the legislation of both or one of the States Parties to the Agreement. Benefits provided: ensuring equal treatment of Moldovan workers with that of native workers in terms of rights, 
obligations, protection and safety at work; old-age pensions and invalidity pensions caused by common illnesses (in the case of bilateral agreements in the field of social security / protection); the pensions and invalidity allowances caused by work accidents or occupational diseases; help in case of death; etc.

Currently, more attention is paid to this phenomenon of migration (both emigration and immigration), both because it has a considerable impact on the development of all sectors of society, and for compliance with the objectives set by the Republic of Moldova for EU membership. Raising awareness of migration as a phenomenon that can produce not only negative social costs, but also positive development results for the country and the commitment to manage the challenges and opportunities of migration, has led to various legislative and political activities of the Government of the Republic of Moldova.

\section{Migration policies}

The migration policies are included in: The National Development Strategy 2020, which provides 7 solutions for the economic growth and poverty reduction. The strategy recognizes at the highest level the need for a coordinated and integrated approach to the migration management. With regard to migration, this includes a special focus on remittances and the emigration of young people. In February 2016, the Government of the Republic of Moldova approved the National Strategy "Diaspora-2025", after a longer process of consulting the diaspora, civil society and academics, as well as international partners. In accordance with the Strategy in question, the Communication and Information Platform in the field of Diaspora, Migration and Development is being developed, the aim of which is to establish a single information desk for the citizens involved in the migration cycle phases, as well as to strengthen the partnerships in areas of common interest. (economic, social, cultural, financial, volunteering, philanthropy) of qualified persons / associations and communities in the diaspora, Government, central and local public authorities, academia, private sector, business, indigenous associations, local communities, civil society.

It is estimated that about a third of the country's population, including children, are temporary or permanent residents abroad, many of them looking 
for better job opportunities. As a result, Moldova has a large diaspora established in over 30 countries around the world. The Moldovan diaspora has the potential to support local development initiatives through financial flows such as remittances, charitable donations and investments, as well as through the transfers of knowledge and skills. The Moldovan diaspora is a major source of income for the national economy. The remittances are sent through both formal and informal channels, which are difficult to estimate, usually through bus drivers or through fellow migrants on their way home. Most remittances are used to meet basic consumption, home purchase and debt repayment. In this context, the activities of IOM Moldova aim at strategies to streamline the use of remittances in Moldova. For example, since 2010, IOM Moldova has supported the PARE $1+1$ program, a program to attract the remittances to the local economy, this program is currently being implemented by the Organization for the Development of Small and Medium Enterprises, the money was mainly used to launch a new private enterprise or to develop an existing enterprise, especially in rural areas (Government Decision nr. 972, 2010).

A new element in the reintegration process, developed and promoted with the support of UNDP is the Interinstitutional Referral Mechanism for the Reintegration of Returned Citizens from Abroad, which involves a Memorandum on the implementation of the Memorandum concluded between several institutions, including Ministry of Health, Labour, and Social Protection, Ministry of Education, Culture and Research, Ministry of Economy and Infrastructure, National Social Insurance House of the Republic of Moldova, National Medical Insurance Company, Public Services Agency and National Employment Agency (concluded on 28.05.2018). The mechanism is elaborated based on the Government Decision no. 724 of September 8, 2017 on the approval of the Action Plan for the years 20172020 on the reintegration of citizens of the Republic of Moldova returned from abroad and Government Decision no. 725 of September 8, 2017 on the Mechanism for coordinating the state policy in the field of diaspora, migration and development. The Parties to the Memorandum share a common vision on the importance of development in the provision of public services for the reintegration of returned citizens and capacity building of relevant institutions, understand the needs of returned citizens and their families in the 
process of economic and social reintegration, assuring access to the qualitative information in the fields of health, employment and social protection, recognition of qualifications obtained abroad, integration of children and young people in educational institutions, issuance of identity documents, other services. The purpose of this Memorandum is to create a framework for the collaboration between the main national actors participating in the reintegration process of the returned citizens. Each institution has appointed responsible persons. The memorandum sets out the responsibilities of the signatory parties.

As a result of the Pandemic, the labour market in most countries has been affected and the impact of Covid on migrants is very high. A study presented during the Diaspora days on 22 August 2020, in an online workshop organized on December 17-18, 2020 by the International Organization for Migration (IOM) and the United Nations Development Program, includes new empirical data on how COVID-19 has affected the migration processes in Moldova, data on the impact of COVID-19, the number and profiles of returning migrants, as well as the specific vulnerabilities of groups affected by declining remittances. Some of the findings of the study launched: most people returning during the pandemic are circular, short-term migrants $(85 \%)$ who have worked abroad in construction (36\%) and home care $(27 \%)$; incomes decreased for $52 \%$ of households during COVID-19; while some households $(26 \%)$ saw a decrease in remittances, others $(20 \%)$ reported an increase in money received from their relatives working abroad; the majority of returnees intend to leave Moldova in the near future (61\%), but at the same time $37 \%$ intend to either find a job or start a business in Moldova; some migrants felt discriminatory and / or hostile attitudes after returning home (24\%); The top 3 conditions for the migrants to return permanently are: economic growth and rising living standards (75\%), employment opportunities (63\%) and the reduction of corruption (59\%) (OIM, 2020).

In addition to the legal framework, the role of institutions in the reintegration of returned migrants is of major importance. The role of the National Employment Agency in the reintegration on the labour market of returned migrants is a very important one.

In accordance with the Law no. $105 / 2018$ on the promotion of employment and unemployment insurance, the National Employment Agency 
has several tasks: participates in the development of policies in the field of employment promotion and migration for work, ensures the implementation of employment measures, labour migration regulations, organizes, coordinates and controls the activity of the territorial subdivisions, monitors the labour market and forecasts these changes at national level, etc. The National Employment Agency, in order to prevent the unemployment, increases employment opportunities for jobseekers, stimulates employers to employ the unemployed and create new jobs, as well as to implement the strategies and policies designed to protect people in unemployment risk, ensuring a high level of employment, adapting the workforce to the requirements of the labour market, implementing active employment services and measures, which comes with a proactive approach to employment and proposes the modern services and measures, adapted to the needs of different categories of persons (young people, unskilled persons, persons with disabilities, persons aged 50 and over, persons released from places of detention, victims of trafficking in human beings and persons who fight with the consumption of narcotic or psychotropic substances, after psychological and social rehabilitation, victims of domestic violence, rural unemployed), as well as employers. The implementation of these measures will contribute to: increasing the competitiveness of the labour force and, respectively, reducing the gap between the labour supply and demand, by implementing new forms of vocational training of the unemployed such as on-the-job training and vocational training, increasing the number of people from vulnerable groups employed in long-term employment as a result of the stimulation of employers who employ unemployed people in these groups; increasing the number of people with disabilities in employment as a result of stimulating employers to create new jobs or adapt existing jobs to the needs of people with disabilities; increasing the labour mobility in line with structural changes in the national economy and labour market requirements; financial support for the unemployed who start their own businesses and create their own jobs; creation of new jobs in rural areas, by awarding grants to support the local initiative projects that create jobs in rural areas; protection of persons through the unemployment insurance.

Certification of knowledge acquired in the non-formal context of returned migrants is one of the active measures provided in the Law 105/2018, which is aimed more at certifying the knowledge and skills acquired in the 
context of non-formal and informal education of returned migrants. The current normative framework includes the Government Decision no. 193/2017 for the approval of the Regulation on adult continuing education, National Action Plan for the implementation of the Republic of Moldova-European Union Association Agreement for the period 2017-2019, the Regulation on the validation of non-formal and informal education approved by Order no. 65/2019 of the Ministry of Education, Culture and Research, the Guide on the implementation of the National System for validation of skills acquired in nonformal and informal education contexts approved by Order no. 1096/2020 of the Ministry of Education, Culture and Research (MECC, 2019). The regulation establishes the normative framework on the certification of competencies, the providers of validation services - ethnic vocational education institutions, the attributions, the management and structure of the Validation Center, the organization and functioning of the Evaluation and Certification Commissions, the Competence evaluation and recognition procedure.

The access of services by returned migrants and the services provided by National Employment Agency in 2020 looks as follows: during 2020, the territorial subdivisions registered as unemployed 1605 people returned to the country, and about 10.5\% (168 people) were employed. A high share of migrants is people from the rural areas $-60.2 \%$ (966 people), of which $22.5 \%$ (361 women). The most requested by the returned migrants were the labour intermediation services, being granted for a number of 526 people, mostly being from rural localities (54.6\%), and the age between 35-49 years (238 pers.). When providing services, the territorial subdivisions identified a total of 1684 problems, and 39.6\% addressed by women. Most of the problems about $87.8 \%$ were those regarding finding a job, about $4.7 \%$ were health problems, about $3.4 \%$ - regarding the social services, and the rest about $3.8 \%$ - were represented other problems. Most of the problems were addressed by migrants returning from Russia (494). More than half approx. 58.6\% of people have secondary education, $23.3 \%$ have secondary vocational education, $8.2 \%$ college education and $9.9 \%$ higher education. In large numbers are observed people of average age $35-49$ years, about $42.4 \%$. As to the countries of return, Russia predominates $-30.8 \%$, followed by Italy with $12.4 \%$, Germany with $12.2 \%$, Poland with 7\%, France with 6.3\%, etc. National Employment Agency involves the returnees from abroad, to inform them about opportunities, the 
portfolio of services and measures on the labour market, some being: Open Doors Day, International Migrant Day, Diaspora Days 2020 with the title "Summer 2020 - New Directions HOME" etc., the information being present on social networks, starting with the planning until their realization.

\section{Conclusions}

In the conditions of development of the economy based on knowledge and innovation, practically all the countries of the world, in order to face the new exigencies related to the economic competitiveness, make great efforts in order to increase the level of education of the citizens and to provide with the labour resources necessary for an economy in development. The extent of migration, especially labour migration, is estimated at about $30 \%$ of the country's human potential, the impact on the social and economic situation in the country being significant. Labour migration has become an important factor in combating poverty and increasing the well-being of the population of the Republic of Moldova. There is a very close relationship between migration and the development prospects of the Republic of Moldova. For this reason, in recent years the interest for the process of integrating the effects of the migratory phenomenon in the development strategies and policies of the Republic of Moldova is growing. In addition to state policies, which need to be continuously improved, the institutions that implement the policies have a great role to play, including the National Employment Agency, which needs to develop innovative methods of working with migrants in order to integrate them into the labour market. Migrants returning to their country of origin could visibly contribute to the country's economic growth, as the persons returning bring with them the new work experiences, new technologies, specific to advanced countries.

\section{References}

ANOFM (2020). Raport de activitate al ANOFM pentru anul 2020. https://anofm.md/ro/node/74

Burdelnii, E., Terzi-Barbăroșie, D. (2013), Suport de curs: Migrația și Dezvoltarea, Cancelaria de Stat a Republicii Moldova, Misiunea OIM Moldova, UNDP Moldova, Chişinău 
Cassarino, J.P. (2004). Theorising Return Migration:The conceptual Approach to Return Migrants Revisted. Revista internațională pentru societăți multiculturală, 6(2), 27.

De Haas Hein, (2007). Remittances, migration and social development: A conceptual review of the literature, United Nations Research Institute for Social Development, Social policy and development paper no.34, 307;

Government Decision no. 724 (2017, September 8) on the approval of the Action Plan for the years 2017-2020 on the reintegration of citizens of the Republic of Moldova returned from abroad

Government Decision no. 725 (2017, September 8) on the Mechanism for coordinating the state policy in the field of diaspora, migration and development

Government Decision nr. 972 (2010, October). Programul de atragere a remitenţelor în economie „PARE 1+1”, Monitorul Oficial al Republicii Moldova, 211-212, art. 1091.

International Labor Organisation (2001). Ratifications for the Republic of Moldova.https://www.ilo.org/dyn/normlex/en/f?p=NORMLEXPUB:1 1200:0::NO::P11200_COUNTRY_ID:102695

Legea nr.105/2018 cu privire la promovarea ocupării forței de muncă și asigurarea de șomaj, MO, 2018, nr.295-308, art.448

Levitt, P., (1998), Social remittances: Migration driven local-level forms of cultural diffusion, International Migration Review, 32(4), 926-948.

MECC (2019). Regulamentul cu privire la validarea educației nonformale și informale, aprobat prin Ordinul MECC nr. 65 din 24.01.2019

Mahroum, S. (2012). Europe and the Immigration of Highly Skilled Labour. International Migration, 39(5), 2001.

OIM (2020). Profilul și provocările lucrătorilor migranți din Republica Moldova în principalele țări de destinație. https://www.md.undp.org/content/moldova/ro/home/library/inclusive_ growth/tendin_ e-actuale-ale-migraiei-forei-de-munc--evideneempirice-i-.html

OIM/UNDP/UNWomen/GMG/SDC/GoRM (2010). " Integrarea migraţiei în strategiile de dezvoltare. Ghid pentru factorii de decizie și specialiști." http://odimm.md// files/rapoarte/Raport\%20PARE\%202016.pdf

Orozco, M.,Welle, K. (2004). Hometown associations and development: Trade Enhancement for the Services Sector Project CARANA Corporation.

Postolachi V., Poalelungi O., Moșneaga V., Gonța V. (2007). Republica Moldova-Problemele migrației. Chișinău, IMSRM; GSEE.

Piore, M.J., (2014), The dual labor market: Theory and implicatons. In D.B. Grusky, K. R. Weisshaar (Eds.), Social Stratification, Routledge, 1196. 
Strategia Naţională „Diaspora-2025” şi Planul de acţiuni pentru anii 20162018 privind implementarea acesteia, aprobată prin HG Nr. 200 din 2602-2016, publicată pe 04-03-2016 în Monitorul Oficial al Republicii Moldova, 49-54, art. 230

Strategia Națională privind ocuparea forței de muncă pentru anii 2017-2021, aprobată prin HG Nr. 1473 din 30.12.2016, publicată pe 07-04-2017 în Monitorul Oficial al Republicii Moldova Nr. 109-118 art. 272

Strategia naţionala de dezvoltare „Moldova 2020”. http://lex.justice.md/index.php?action=view\&view= doc\&lang =1\&id=345635

Vaculovschi Dorin (2017). Migrație și dezvoltare. Aspecte social-economice - Manual, Chișinău, ISBN 978-9975-89-074-8

Vaculovschi, D., Vaculovschi, E. (2016). Economic, social and gender aspects of the migration in Moldova, Eastern European Journal of Regional Studies, 2(1), 132-142.

Сталкер Питер.,(2015) Международная миграция, М.Книжный клуб, р 16 